\title{
DESAIN PEMBELAJARAN UNTUK GURU TK INKLUSIF
}

\author{
Suparno \\ FIP Universitas Negeri Yogyakarta (e-mail: sup-plb@telkom.net; \\ HP: 08122960788)
}

\begin{abstract}
Developing an Instructional Design to Improve Kindergarten Teachers' Competencies in the Perspective of Inclusive Education. This study aims to develop an instructional design set to improve kindergarten teachers' competencies in inclusive education in terms of pedagogic, personal, social, and professional aspects. It was a research and development study involving the stages of predevelopment, model development, product validation. The sample comprised 34 kindergarten teachers selected by the purposive sampling technique. The results show that: (1) the majority of kindergarten teachers do not understand the concept of inclusive education, (2) a set of indicators of kindergarten teachers' competencies in inclusive education and a set of competency instruments and instructional design can be produced; (3) the implementation of the instructional design model is capable of increasing kindergarten teachers' competencies in inclusive education. The instructional design significantly improves kindergarten teachers' pedagogic, social, and professional competencies, but it does not significantly increase the personal competency.
\end{abstract}

Keywords: inclusive education, kindergarten teachers

\section{PENDAHULUAN}

Pendidikan inklusif merupakan fenomena global untuk memberikan layanan dan hak-hak anak bagi semua anak agar memperoleh pendidikan tanpa ada batasan-batasan maupun diskriminasi. Inklusi peduli mengenai hambatan-hambatan untuk belajar dan berpartisipasi bagi semua anak, tanpa menghiraukan masalah etnik, gender, latar belakang sosial, orientasi seksual, kecacatan atau prestasi yang dicapai, dan fokus pada dasar kebijakan pendidikan secara global. Oleh karena itu, diperlukan peningkatan kemampuan guru untuk mengimplemantasikan in- klusi dalam praktek sehari-hari (Booth: 2003:vi).

Zalizan Jelas (Abosi, 2008:5) menjelaskan bahwa pendidikan inklusif merupakan suatu isu integrasi menuju partisipasi anak berkebutuhan khusus untuk memperoleh jaminan pendidikan. Lebih lanjut, Abosi (2008:5) mendefinisikan inklusi sebagai: (1) pengakuan terhadap semua anak dan remaja dapat belajar dan mereka memerlukan dukungan; (2) penerimaan dan penghargaan bahwa semua siswa memiliki cara yang berbeda, serta kebutuhan belajar yang berbeda pula sebagai suatu nilai keseimbangan yang merupakan bagian 
dari kehidupan manusia yang wajar; (3) struktur pendidikan, sistem dan metodologi pembelajaran yang memungkinkan bagi siswa.

Konsep inklusi menekankan pada upaya pemenuhan kebutuhan pendidikan bagi anak-anak berkebutuhan khusus. Secara operasional, SaponShevin (O'Neil, 1994:1) mendefinisikan pendidikan inklusif sebagai suatu sistem layanan pendidikan khusus yang mensyaratkan agar semua anak berkebutuhan khusus dilayani di sekolahsekolah terdekat di kelas biasa bersama teman-teman seusianya. Untuk itu, perlu adanya restrukturisasi di sekolah sehingga menjadi komunitas yang mendukung pemenuhan kebutuhan khusus bagi setiap anak. Pendidikan inklusi mempercayai bahwa semua anak berhak mendapatkan pelayanan pendidikan yang baik sesuai dengan usia atau perkembangannya, tanpa memandang derajat, kondisi ekonomi, ataupun kelainannya. Penting bagi guru untuk disadari bahwa di sekolah mereka dapat membuat penyesuaian pendidikan bagi anak-anak berkebutuhan khusus ketika mereka memiliki pandangan pendidikan yang komprehensif, yang terpusat pada anak.Namun demikian, mereka mungkin masih memerlukan pelatihan tentang metode atau strategi khusus yang akan diterapkan di sekolah.

Daribeberapa konsep dan pandangan mengenai pendidikan inklusif sebagaimana diuraiakan di atas, ada beberapa hal yang penting untuk menjadi penekanan di sini, yaitu (1) inklusi merupakan suatu sistem layanan pendidikan khusus yang mensyaratkan agar semua anak berkebutuhan khusus di- layani di sekolah-sekolah terdekat di kelas biasa bersama teman-teman seusianya; (2) tujuan utama pendidikan inklusif bagi siswa yang memiliki hambatan adalah keterlibatan yang sebenarnya pada tiap-tiap anak dalam kehidupan sekolah yang menyeluruh, dengan menghilangkan hambatan-hambatan untuk belajar dan berpartisipasi tanpa diskriminasi; (3) implementasi pendidikan inklusif adalah penerimaan anak-anak yang memiliki hambatan ke dalam kurikulum, lingkungan, interaksi sosial, dan konsep diri (visi-misi) sekolah; serta (4) dalam tataran operasional, inklusi adalah proses pembelajaran yang dirancang secara khusus serta bantuan bagi anak-anak berkebutuhan khusus dalam kontekslingkungan pendidikan reguler.

Proses pelaksanaan pendidikan inklusif di sekolah-sekolah umum telah menyebabkan adanya perubahan tuntutan yang besar bagi guru-guru di sekolah tersebut. Perubahan yang mendasar adalah adanya pergeseran pola pembelajaran, yang semula menggunakan pendekatan klasikal untuk semua siswa di kelas menjadi pendekatan pembelajaran yang berbasis kebutuhan individual untuk setiap siswa dalam setting kelas bersama. Anak-anak adalah individu yang unik, yang memiliki bermacam-macam minat bidang dan tingkat penguasaan, komunikasi dan strategi belajar, kecemasan dan kekhawatiran. Menurut Johnsen, 2003: 288-289, siswa-siswa tertentu memiliki kebutuhan khusus akan bantuan karena alasan yang berbeda-beda.

Berkenaan dengan proses pembelajaran, guru-guru di sekolah inklusi memiliki tugas berat dalam mengadap- 
tasikan lingkungan sesuai dengan kebutuhan dan kemampuan belajar setiap siswa. Umumnya, setiap sekolah akan memiliki konsep dan strategi yang bervariasi dalam mengembangkan lingkungan belajarnya. Kendati begitu, strategi yang terbukti efektif pada satu jenis tantangan pembelajaran tampaknya akan potensial dalam memberi pengajaran pada siswa dengan jenis kebutuhan yang lain (Smith, 2006:84) Strategi-strategi pembelajaran yang dikembangkan untuk anak berkebutuhan khusus, pada dasarnya sering terbukti menjadi cara-cara yang praktis dalam pembelajaran seluruh siswa.

Seharusnya, pendidikan inklusif dapat dimulai sejak anak usia dini. Selain undang-undang dan peraturan yang mendukung terselenggaranya pendidikan anak usia dini, secara konseptual dan kajian-kajian ilmiah mengenai perkembangan anak, telah menunjukkan adanya nilai-nilai positif dalam pemberian layanan pendidikan sejak dini. Hadis (2007) menjelaskan bahwa pengaruh yang paling mengena dan dapat meninggalkan kesan yang lama harus dilakukan pada saat yang tepat, yaitu pada masa kritis atau masa sensitif. Oleh karena itu, perlunya rangsangan diberikan pada usia dini yang dapat meningkatkan seluruh aspek perkembangan juga didasarkan pada pandangan tersebut. Keterlambatan atau pengabaian pemberian rangsangan pada saat yang tepat atau pada periode kritis akan memberi dampak negatif bagi perkembangan anak.

Pentingnya peranan guru dalam proses pembelajaran anak berkebutuhan khusus usia dini, terutama dalam menumbuhkan kepercayaan dan penyesuaian diri dalam belajar sesungguhnya telah disadari oleh banyak pihak. Setidaknya, ada empat peran guru untuk anak-anak usia dini, sebagaimana dikemukakan Katz, yaitu: merawat, membimbing dan memberi dukungan emosional, mendidik, dan memberikan fasilitas. Sebaliknya, Sally Cartwright mengatakan bahwa kematangan, semangat dan integritas seorang guru adalah nilai yang sangat penting, lebih dari sekedar mencintai dan mendidik atau memberi pengalaman (Essa, 2003: 83). Keempat peran dimaksud, secara substansial sebenarnya sudah tercakup dalam empat standar inti kompetensi guru. Kompetensi yang dimaksud adalah kemampuan sesorang dalam melaksanakan tugas-tugasnya. Virgil (2006) dan Kiymet (2009) mengemukakan bahwa kompetensi merujuk pada aspek pengetahuan, sikap, keterampilan, motivasi, dan kemampuan awal dalam konteks penyesuaian dan pengembangan yang diperlukan untuk menyelesaikan suatu tugas secara efektif dan efisien berdasarkan ukuran standar minimal. Keputusan Menteri Pendidikan Nasional Nomor 045/2002, menyebutkan kompetensi sebagai seperangkat tindakan cerdas dan penuh tanggung jawab yang dimiliki seseorang sebagai syarat untuk dianggap mampu oleh masyarakat dalam melaksanakan tugas-tugas sesuai pekerjaan tertentu.

Peraturan Menteri Pendidikan Republik Indonesia Nomor 16 Tahun 2007, Pasal 1 Ayat 1 menjelaskan bahwa setiap guru wajib memenuhi standar kualifikasi akademik dan kompetensi guru yang berlaku secara nasional. Terdapat 
empat kompetensi utama, yaitu (1) pedagogik; (2) kepribadian; (2) sosial; dan (4) profesional. Pedagogik adalah konsep yang berorientasi praksis, yaitu kemampuan guru dalam merencanakan dan melaksanakan proses pembelajaran di sekolah, di antaranya mencakup pemahamaan peserta didik, penguasaan prinsip dan teori belajar, kurikulum, pengelolaan kelas, serta evaluasi pembelajaran. Kepribadian dalam konteks penelitian ini berorientasi perilaku positif yang ditampilkan seorang guru dalam proses belajar, yaitu karakter yang mantap, stabil, dewasa, arif, dan berakhlak mulia. Kompetensi sosial berkenaan dengan sikap dan kemampuan membangun komunikasi, berinteraksi, bekerjasama, empatik, dan peka terhadap permasalahan peserta didik dalam proses pembelajaran di sekolah. Kompetensi profesional adalah kesanggupan guru berkenaan dengan penguasaan materi yang diampunya, dan implementasinya, baik dalam proses pembelajaran maupun dalam kehidupan sehari-hari.

Sekarang ini, menurut Hadadian (2007:103), inklusi anak berkebutuhan khusus di kelas umum telah berkembang dari suatu argumentasi teoretik ke arah fenomena yang lebih luas. Berkenaan dengan proses inlusif, diasumsikan bahwa guru-guru di sekolah umum harus memiliki sejumlah pengetahuan tertentu mengenai pendidikan khusus, siswa berkebutuhan khusus, teknikteknik pembelajaran, dan pengembangan kurikulum. Asumsi lainnya adalah bahwa guru-guru kelas memiliki kemauan untuk melakukan perubahan dari paradigma lama ke paradigma baru.

Tanggung jawab guru untuk melayani pendidikan anak-anak berkebutuhan sangat berat, yang sesungguhnya sulit untuk didefinisikan. Tanggung jawab yang diharapkan menurut Learner (2006:145) adalah; (1) melakukan setting program untuk identifikasi, assessment, dan mengajar siswa; (2) berpartisipasi dalam screening, assesment, dan evaluasi siswa; (3) melakukan kolaborasi dengan staf dalam merancang dan melaksanakan pembelajaran; (4) memahami metode assesment formal dan assesment pengganti; (5) berpartisipasi dalam tim pembelajaran individual; (6) implementasi pembelajaran individual; (7) wawancara dan kerjasama dengan orang tua; dan (8) membantu siswa dalam memahami dirinya, serta menumbuhkan kepercayaan dalam belajar. Dari konsep tersebut terlihat adanya tanggung jawab yang besar bagi guru-guru dalam konteks pembelajaran di kelas, terutama terkait pemahaman kondisi anak melalui asesment, pendekatan pembelajaran secara individual, serta bagaimana guru dapat membantu anak dalam memahami dirinya dan kepercayaannya dalam belajar.

Berdasarkan kajian konsep dan teori yang telah disampaikan di atas, secara substansial terdapat dua komponen utama dalam pengembangan kompetensi guru pendidikan inklusif. Pertama, memiliki kompetensi inti guru yang telah distandarkan dan dikembangkan menjadi kompetensi guru PAUD/TK/ RA, mencakup kompetensi (a) pedagogik, (b) kepribadian, (c) sosial, dan (d) profesional, (Permendiknas No. 16 Ta- 
hun 2007). Kedua, kompetensi kekhususan dalam pendidikan inklusif untuk TK, yaitu memiliki pemahaman dan kemampuan dalam hal (1) pengembangan pembelajaran melalui bermain; (2) karakteristik dan kebutuhan belajar anak berkebutuhan khusus; (3) assesment pembelajaran anak berkebutuhan khusus; (4) menciptakan lingkungan pembelajaran yang ramah; (5) program pembelajaran individual; (6) proses pembelajaran aktif dan kreatif; dan (7) evaluasi pembelajaran anak berkebutuhan khusus. Kendati demikian, masih ada beberapa komponen kekhususan lain yang sesungguhnya juga diperlukan, yaitu bidang kekhususan berdasarkan jenis kelainan masing-masing anak.

MenurutCholes (Ndikana, 2007:129), keberhasilan memfasilitasi pendidikan inklusif terletak pada peran para pendidik. Implikasi selanjutnya adalah diperlukan adanya perubahan sistem pendidikan agar para pendidik lebih efektif dan memiki perhatian. Jika inklusi ingin berhasil, maka guru menjadi faktor yang paling penting yang harus diperhatikan. Masih berkenaan dengan peran guru, hasil studi Davis and Green, 1999, Gordon, 2000, Baker, 2000, Ndikana (2007:129) menunjukkan bahwa guruguru berperan utama dalam pendidikan inklusif. Namun demikian, dalam pelaksaan pendidikan inklusif di sekolah, kompetensi guru yang diharapkan masih sangat sulit dicapai.

Mempersiapkan guru yang berkompeten dalam pendidikan inklusif merupakan suatu keniscayaan, kendati hal tersebut tidak mudah dilakukan. Hasil penelitian yang dilakukan oleh Scruggs \& Mastropieri (Ndikana, 2007:130) da- lam studi meta analisisnya di Amerika, menunjukkan bahwa guru-guru seringkali tidak dipersiapkan dengan baik untuk menghadapi anak-anak berkebutuhan khusus secara signifikan dalam upaya pendidikan inklusif. Dalam hal ini, kesiapan guru baik secara mental maupun kompetensi sangat diperlukan dalam menukung keberhasilan pendidikan inklusi di sekolah. Untuk itu, perlu dipersiapkan dengan baik dalam memberikan layanan pendidikan bagi anak-anak berkebutuhan khusus di sekolah umum.

Mengutip analisis Johnsen (2003: 352-353) secara substansial disebutkan adanya tiga aspek pengetahuan profesional yang harus dimiliki guru pendidikan khusus, yaitu pengetahuan faktual (atau pengetahuan proporsional atau pengetahuan formal), pengetahuan praktis (atau keterampilan), dan pengetahuan familiaritas (atau tacit knowing). Pengetahuan faktual adalah pengetahuan yang dapat diekspresikan melalui teori-teori, kaidah-kaidah, prinsip-prinsip, konsep-konsep, dan definisi. Pengetahuan praktis atau keterampilan adalah penguasaan teknik-teknik tertentu. Pengetahuan familiaritas adalah aspek pengetahuan yang sulit dijelaskan, seperti kemampuan untuk menangani suatu situasi yang unik atau kemampuan untuk mengenali wajah. Namun, pengetahuan faktual saja tidak cukup digunakan sebagai "resep" untuk praktek seorang guru. Hal ini terjadi karena guru seringkali dihadapkan pada situasi-situasi yang unik. Untuk itu, sebaiknya program pengembangan guru pendidikan khusus dirancang sedemikian rupa sehingga mencakup se- 
mua aspek pengetahuan profesional tersebut.

Penelitian ini bertujuan untuk (1) memperoleh informasi mengenai kebutuhan guru taman kanak-kanak dalam memberikan layanan anak berkebutuhan khusus; dan (2) mengembangan desain pembelajaran untuk meningkatkan kompetensi guru TK dalam perspektif pendidikan inklusif.

\section{METODE}

Subjek dalam penelitian adalah para guru taman kanak-kanak penyelenggara pendidikan inklusif di Propinsi Daerah Istimewa Yogyakarta, yang diambil secara purposive sampling, dengan mempertimbangan pengalaman dan keberadaan anak-anak berkebutuhan khusus. Untuk kepentingan penelitian pendahuluan, ditetapkan lima orang guru TK penyelenggara pendidikan Inklusif, yaitu satu orang guru TK di Kabupaten Bantul, dua orang guru TK di Kota Yogyakarta, dan dua orang guru TK di Kabupaten Sleman Yogyakarta.

Selanjutnya, pada tahap pengembangan lebih luas ditetapkan 34 orang guru taman kanak-kanak penyelenggara pendidikan inklusif di Propinsi Daerah Istimewa Yogyakarta, masingmasing meliputi sebelas orang guru TK penyelenggara pendidikan inklusif di Kota yogyakarta, empat orang guru TK di Kabupaten Bantul, tujuh orang guru TK di Kabupaten Sleman, tujuh orang guru TK di Kabupaten Gunung Kidul, dan lima orang guru TK Kabupaten Kulon Progo.

Penelitian ini merupakan penelitian pengembangan yang bertujuan me- ngembangkan dan menvalidasi produk berupa desain pembelajaran. Terkait dengan tujuan tersebut, rancangan penelitian menggunakan pendekatan penelitian dan pengembangan (Walter $R$ Borg dan Gall, Maredith, 1989). Prosedur penelitian ini dilakukan dalam tiga tahapan utama, yaitu (1) tahap pra-pengembangan melalui penelitian pendahuluan; (2) tahap pengembangan; dan (3) tahap validasi.

Pada tahap I, dilakukan kajian-kajian teoretik, observasi, dan survei lapangan, yaitu dengan menyebarkan kuesioner kepada para guru TK yang memiliki siswa berkebutuhan khusus di wilayah Propinsi Daerah Istimewa Yogyakarta. Tujuannya adalah untuk memperoleh data atau informasi tentang peta kompetensi guru dalam rangka pemberian layanan pendidikan bagi anak-anak berkebutuhan maupun pelaksanaan pendidikan inklusif yang sudah dilakukan di sekolah. Data hasil penelitian pendahuluan yang telah diperoleh selanjutnya diolah dan dianalisis secara deskriptif komparatif. Hasil analisis tahap I selanjutnya dijadikan acuan dan pertimbangan dalam penyusunan desain pembelajaran untuk pengembangan kompetensi guru.

Selanjutnya, pada tahap II berupa pengembangan desain pembelajaran yang dirancang berdasarkan hasil penelitian pendahuluan dan kajian teoretik yang telah dihasilkan sebelumnya. Desain pembelajaran yang dikembangkan di sini berupa modul (internalcontent) di mana substansi pembelajaran ditampilkan secara lengkap di dalam desain pembelajaran yang dimaksud. Cakupan desain pembelajaran terdiri 
atas tujuh unit pembelajaran, yaitu (1) wawasan pendidikan inklusif; (2) konsep dasar anak berkebutuhan khusus; (3) kurikulum teradaptasi; (4) strategi pembelajaran inkusif; (5) lingkungan pembelajaran inklusif; (6) program pembelajaran individual; dan (7) evaluasi portofolio.

Tahap III berupa validasi produk, yang dilakukan secara konstruk dan empirik terhadap desain pembelajaran yang telah disusun. Validasi dimaksudkan untuk memperoleh informasi mengenai tingkat kelayakan desain pembelajaran yang telah disusun guna pengembangan kompetensi guru TK dalam perspektif pendidikan inkusif. Validasi konstruk dilakukan dengan teknik delphi dalam konteks focus group discussion (FGD) terhadap tujuh orang pakar, yaitu dua orang pakar pendidikan inklusif, dua orang pakar pendidikan khusus, dua orang pakar anak usia dini, dan satu orang pakar metodologi, serta 22 orang praktisi guru taman kanakkanak penyelenggara pendidikan inklusif.

Validasi empirik dilakukan melalui ujicoba lapangan dalam proses pelatihan langsung disertai pendampingan di sekolah, dengan rancangan quasi-experiment dengan pendekatan one group pretest-posttest. Ujicoba dilakukan terhadap sampel penelitian yang sudah direncanakan sebelumnya, dilakukan dalam dua tahapan secara terbatas, dan diperluas (34 orang guru). Ujicoba juga dimaksudkan untuk memperoleh informasi atau data yang diperlukan dalam memantapkan desain pembelajaran yang telah disusun. Eksperimen dilakukan dalam lima kali perlakukan seperti terlihat pada Tabel 1 berikut.

Tabel 1: Desain Pelaksanaan Uji Lapangan

\begin{tabular}{lccccc}
\hline Pertemuan ke & 1 & 2 & 3 & 4 & 5 \\
\hline Perlakuan & X1 & X2 & X3 & X4 & X5 \\
\hline Pengamatan & O1 & O2 & O3 & O4 & O5
\end{tabular}

Keterangan:

$X=$ Pendampingan pendidikan inklusif

$\mathrm{O}=$ Data $\mathrm{X}$ dikumpulkan

Data hasil penelitian yang telah terkumpul, selanjutnya diolah dan dianalisis secara deskriptif kualitatif dan kuantitaif. Guna menjawab permasalahan-permasalahan penelitian dan mengetahui efektifitas produk yang dihasilkan dalam penelitian ini, maka data hasil penelitian yang telah terkumpul selanjutnya diolah dan dianalisis dengan teknik (1) analisis deskriptif dan (2) analisis perbedaan rata-rata $(u j i-t)$. Analisis data dilakukan sesuai dengan tahapan dalam penelitian, dengan ter- 
lebih dahulu dilakukan uji asumsi; normalitas dan homogenitas data.

\section{HASIL PRAPENGEMBANGAN}

Berdasarkan penelitian pendahuluan pada tahap prapengembangan, data yang telah diperoleh dapat dideskripsikan sebagai berikut.

Hasil studi dokumentasi, ada dua hal yang dikaji. Pertama, Peraturan Menteri Pendidikan Nasional Republik Indonesia Nomor 16 Tahun 2007 Tentang Standar Kualifikasi dan Kompetensi Guru, hasil studi dokumentasi menjukkan adanya empat kompetensi utama, yaitu kompetensi pedagogik, kepribadian, sosial dan profesional, selanjutnya empat kompetensi utama tersebut diuraikan menjadi 24 standar inti guru TK. Kedua, studi dokumentasi mengenai TK penyelenggara pendidikan inklusif di Daerah Istimewa Yogyakarta, hasilnya menunjukkan hanya satu TK penyelenggara pendidikan inklusif yang telah tercatat secara resmi pada Dinas Pendidikan, Pemuda dan Olahraga, yaitu TK ABA Nitikan Yogyakarta.

Hasil survei yang dilakukan terhadap 94 orang guru-guru TK di Daerah Istimewa Yogyakarta, kembali dan dapat dianalisis secara deskriptif sebanyak 86 kuesioner. Melalui pertanyaan-pertanyaan mendasar yang diajukan kepada responden berkenaan dengan pendidikan inklusif untuk anak usia dini di TK, hasilnya adalah sebagai berikut.

Pertama, ada sebagian guru-guru TK di Daerah Istimewa Yogyakarta (32,5\%) atau 28 dari 86 orang guru yang telah mengenal istilah pendidikan inklusif, seperti tampak pada Diagram 1.

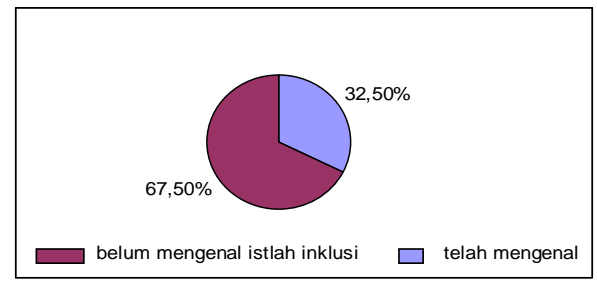

Kedua, sebagian besar guru-guru TK di Propinsi Daerah Istimewa Yogyakarta (94\%) atau 78 dari 86 orang guru belum memahami tentang konsep dan pelaksanaan pendidikan inklusif, seperti tampak pada Diagram 2.

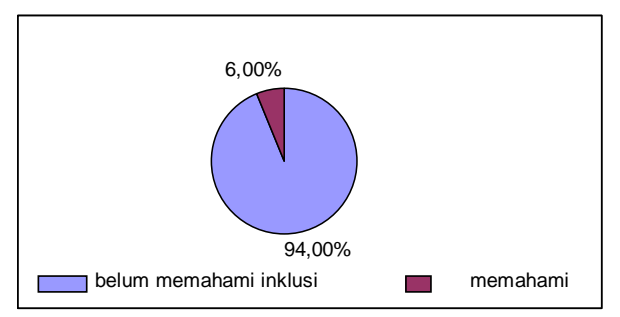

TK di Propinsi Daerah Istimewa Yogyakarta $(95,3 \%)$ atau 82 dari 86 orang guru memerlukan kompetensi khusus berkenaan dengan pelaksanaan pendidikan inklusif untuk anak usia dini di taman kanak-kanak, seperti tampak pada Diagram 3.

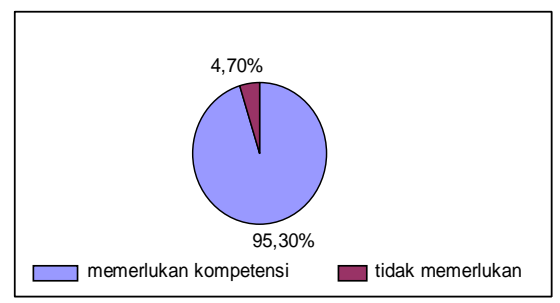

Keempat, substansi/materi yang diperlukan guru-guru TK di Propinsi Daerah Istimewa Yogyakarta berkenaan dengan pelaksanaan pendidikan inklusif adalah (1) wawasan pendidikan inklusif; 79 orang guru $(91,8 \%)$; (2) pe- 
mahaman anak berkebutuhan khusus, 82 orang guru (95,3\%); (3) pendekatan pembelajaran anak berkebutuhan khusus, 82 orang guru (95,3\%); (4) kurikulum terakomodasi, 74 orang guru (86\%); (5) evaluasi pembelajaran 80 orang guru (93\%); dan (6) manajemen kelas, 65 orang guru $(75,5 \%)$ dari 86 orang guru, seperti tampak pada Diagram 4.

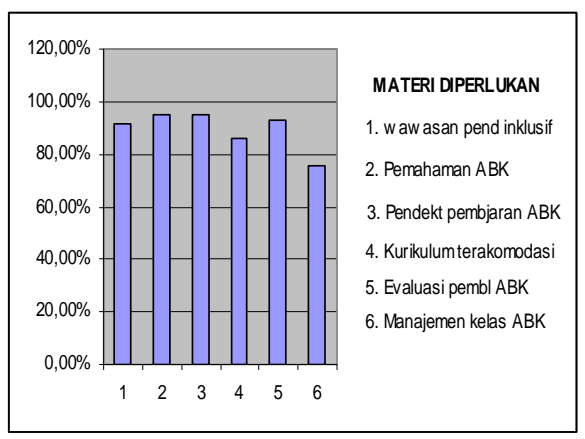

\section{HASIL PENGEMBANGAN}

Berdasarkan hasil penelitian pendahuluan, analisis kebutuhan dan kajian teoretik yang telah dilakukan, dihasilkan seperangkat desain pembelajaran pembelajaran inklusif untuk guru ta- man kanak-kanak. Garis besar substansi desain pembelajaran yang dihasilkan yang merupakan produk penelitian pengembangan ini mencakup unit-unit kegiatan pembelajaran, yaitu: (1) wawasan pendidikan inklusif, mencakup 4 indikator, dengan 14 topik bahasan; (2) konsep dasar anak berkebutuhan khusus, mencakup 3 indikator dengan 16 topik bahasan; (3) pengembangan kurikulum terakomodasi dengan 5 indikator dan 15 topik bahasan; (4) lingkungan pembelajaran yang kondusif, mencakup 4 indikator dengan 15 topik bahasan; (5) strategi pembelajaran inklusif, mencakup 5 indikator dengan 15 topik bahasan; (6) program pembelajaran individual; mencakup 5 indikator dan 16 topik bahasan; dan (7) evaluasi pembelajaran portofolio, mencakup 4 indikator dengan 12 topik bahasan.

Selanjutnya, berdasarkan hasil validasi empirik substansi yang dikembangkan terhadap sampel penelitian, nilai rerata untuk setiap tahapan dapat dilihat pada Tabel 2.

Tabel 2: Data Rerata (Time series Samples Statistics, $n=34$ )

\begin{tabular}{ccccc}
\hline Pertemuan & \multicolumn{4}{c}{ Rerata } \\
\cline { 2 - 5 } Ke & Pedagogik & Kepribadian & Sosial & Profesional \\
\hline 1 & 63.26 & 43.82 & 32.56 & 37.68 \\
2 & 92.48 & 43.91 & 32.74 & 43.26 \\
3 & 106.34 & 44.97 & 32.89 & 46.43 \\
4 & 111.32 & 44.18 & 33.02 & 48.72 \\
5 & 113.79 & 44.24 & 33.06 & 49.29 \\
\hline
\end{tabular}

Sumber: Analisis data primer, 2010 
Efektivitas Isi Desain Pembelajaran

Berdasarkan uji lapangan yang diperluas terhadap sampel penelitian, sebagaimana ditampilkan pada Tabel 3, nilai perbedaan pretest dan posttest un- tuk masing-masing aspek kompetensi utama adalah sebagai berikut.

\section{Tabel 3: Hasil Ujicoba terhadap Pengguna Guru TK}

\begin{tabular}{|c|c|c|c|c|c|}
\hline \multirow[b]{2}{*}{$\begin{array}{l}\text { Sumber } \\
\text { Analisis/Kompetensi }\end{array}$} & \multicolumn{3}{|c|}{ Perbedaan } & \multirow[b]{2}{*}{$\mathrm{df}$} & \multirow[b]{2}{*}{$\begin{array}{l}\text { Sig. } \\
(0.05)\end{array}$} \\
\hline & Mean & thit & tab & & \\
\hline Pedagogik & 50.529 & 55.848 & 1.690 & 33 & .000 \\
\hline Kepribadian & .412 & 1.623 & 1.690 & 33 & .114 \\
\hline Sosial & 1.147 & 3.763 & 1.690 & 33 & .001 \\
\hline Profesional & 11.618 & 33.614 & 1.690 & 33 & .000 \\
\hline Total & 63.059 & 58.676 & 1.690 & 33 & .000 \\
\hline
\end{tabular}

Sumber: Hasil analisis data primer, 2010

Berdasarkan hasil analisis uji lapangan desain pembelajaran yang telah dikembangkan terhadap para pengguna, sebagaimana terlihat pada Tabel 3 di atas, menunjukkan: (1) adanya perbedaan yang signifikan untuk peningkatan kompetensi pedagogik dengan nilai signifikansi $p=0,00$, (2) kompetensi sosial, dengan nilai signifikansi $p=0,01$; (2) kompetensi profesional dengan nilai signifikansi $p=0,00$; (3) kompetensi keseluruhan dengan nilai signifikansi $p=$ 0,00 ; (4) ada perbedaan yang tidak signifikan untuk kompetensi kepribadian dengan nilai signifikansi $p=0,114$. Terjadinya perbedaan yang tidak signifikan untuk kompetensi kepribadian ini dimungkinkan karena nilai awal yang sudah baik. Artinya, skor lambat bergerak dalam posisi yang sudah tinggi.
Kendati demikian, hasil ini secara keseluruhan menunjukkan bahwa desain pembelajaran yang diujicobakan telah sesuai dengan kebutuhan dan layak digunakan untuk meningkatkan kompetensi guru taman kanak-kanak dalam perspektif pendidikan inklusif di Daerah Istimewa Yogyakarta.

\section{KESIMPULAN}

- Dari hasil penelitian pendahuluhan diketahui bahwa (1) sebagian guruguru TK di DI Yogyakarta (32,5\%) atau 28 dari 86 orang guru telah mengenal istilah pendidikan inklusif; (2) sebagian besar $(94 \%)$ dari 86 orang responden belum memahami konsep dan pelaksanaan pendidikan inklusif, dan (3) sebagian besar $(95,3 \%)$ guruguru TK di Propinsi Daerah Istimewa 
Yogyakarta memerlukan kompetensi khusus berkenaan dengan pelaksanaan pendidikan inklusif.

- Ada beberapa substansi yang yang diperlukan guru untuk dapat mengimplementasikan pendidikan inklusif di sekolah yaitu, (1) pemahaman tentang pendidikan inklusif; (2) anakanak berkebutuhan khusus; (3) pengembangan kurikulum; (4) proses pembelajaran; dan (5) evaluasi untuk anak berkebutuhan khusus. Dari kajian teoretik, diperlukan pula adanya substansi mengenai program pembelajaran individual, dan lingkungan pembelajaran inklusif,

- Telah dihasilkan produk pengembangan yang telah teruji validitas konstruk dan empiriknya berupa desain pembelajaran yang dipergunakan untuk peingkatan kompetensi guru taman kanak-kanak dalam perspektif pendidikan inklusif. Produk desain pembelajaran yang dihasilkan dalam penelitian ini berupa modul internal content, yang terdiri atas tujuh unit materi yaitu; unit 1: wawasan pendidikan inklusif; unit 2 : konsep anak berkebutuhan khusus; unit 3: pengembangan kurikulum teradaptasi; unit 4: strategi pembelajaran inklusif; unit 5: lingkungan pembelajaran inklusif; unit 6: program pembelajaran individual; unit 7: evaluasi pembelajaran portofolio.

- Hasil ujicoba pengembangan yang telah dilakukan menunjukkan adanya gradasi perkembangan sekor kompetensi pada tiap tahapan kegiatan. Untuk itu secara substantif teoretis, dapatdibangun sebuah proposisi berdasarkan hasil penelitian ini, yaitu: semakin intensif aktifitas pendampingan pembelajaran dilakukan, maka semakin meningkat kompetensi yang dicapai oleh seorang guru. Secara bagian dan keseluruhan hasil ujicoba menunjukkan signifikansi untuk kompempetensi utama pedagogik, sosial, dan profesional; dan ada perbedaan yang tidak signifikan untuk kompetensi kepribadian. Dengan demikian, desain pembelajaran yang dikembangkan telah sesuai dan layak untuk digunakan.

\section{REKOMENDASI}

Melalui penelitian ini, telah dihasilkan seperangkat rancangan pembelajaran yang telah teruji validitas dan reliabilitasnya. Untuk itu, kepada para pembaca dan pengambil kebijakan dapat mengambil manfaat dalam upaya pengembangan dan peningkatan layanan pendidikan anak-anak usia dini berkebutuhan khusus. Hal ini terutama berkenaan dengan peningkatan kompetensi guru (TK) dalam memberikan layanan pendidikan anak-anak usia dini berkebutuhan khusus melalui program pendidikan inklusif.

Kompetensi guru-guru TK dalam bidang pendidikan inklusif sangat penting dan perlu mendapat perhatian yang sungguh-sungguh, terutama dari para pengambil kebijakan. Anak-anak usia dini berkebutuhan khusus perlu diberi layanan pendidikan yang sesuai dengan kondisi dan kemampuannya agar dapat mencapai hasil yang optimal. Anak-anak dapat dibimbing dan dibiasakan untuk melakukan kebiasaan-kebiasaan yang baik dalam upaya mengeksplorasi potensi-potensi yang di- 
miliki masing-masing anak secara individual.

Selanjutnya, sebagai tindak lanjut dari rekomendasi yang telah dikemukakan diatas, dengan memperhatikan adanya keterbatasan-keterbatasan yang ada, maka perlu adanya penelitian lebih lanjut yang dapat menjawab permasalahan-permasalahan yang timbul yang belum terliput dalam penelitian ini.

\section{UCAPAN TERIMA KASIH}

Dengan diterbitkannya artikel penelitian ini, ucapan terima kasih disampaikan kepada DP2M Dikti Kementerian Pendidikan Nasional melalui Lembaga Penelitian Universitas Negeri Jakarta, atas dukungan biaya penelitian yang diberikan. Ucapan terima kasih juga disampaian kepada Subdin PLB Dinas Pendidikan, Pemuda, dan Olahraga Provinsi Daerah Istimewa Yogyakarta atas dukungannya selama pelaksanaan penelitian. Terakhir, ucapan terima kasih disampaian kepada Tim Redaktur dan Staf Cakrawala Pendidikan yang telah memberikan review dan kesempatan untuk menerbitkan artikel ini.

\section{DAFTAR PUSTAKA}

Abosi, Okey \& Koay, TL. 2008. "Attaining Development Goal of Children with Disabilities: Implication for Inclusive education". International Journal of Special Education, Vol. 23, Number 3.

Essa, Eva L. 2003. Introduction to Early Childhood Education. Clifton Park, New York: Thomson Learning.
Hadis, Fawzia Aswin. 2007. “Fungsi Stimulasi bagi Perkembangan Anak: Tinjauan Psikologis". Buletin PADU. Vol. 6, Nomor 3.

Friend, Marilyn. 2005. Special Education: Contemporary Perspectives for School Professionals. Boston: Pearson Education, Inc.

Gould, Patti and Sullivan, Joyce. 1999. The Inclusive Early Classroom: Easy Ways to Adapt Learning Centers for All Children, Beltsville, MD: Gryphon House, Inc.

Hadadian, Azar \& Chiang, Linda. 2007. "Special Education Training and Pre-Service Teachers". International Journal of Special Education. Vol. 22, Number 1.

Kiymet, S. 2010. Teachers' Competencies, dari (http://www.internationaljournal-of-axiology.net/articole/nr13/art12.pdf). Diunduh Tanggal 6 Januari 2010.

Virgil E., Varverl. Jr. 2010. Master Online Teacher Competencies. dari (http://www.westga.edu/-distance/ojdlaspring101 Narvel101.htm). Diunduh Tanggal 18 Mei 2010.

Johnsen, BH \& Skjorten, Miriam D. 2003. Pendidikan Kebutuhan Khusus, sebuah Pengantar. (Terjemahan). Bandung: Program Pascasarjana UPI.

Learner, JW dan Kline, F. 2006. Learning Disabilities and Related Disorder, 
Characteristic and Teaching Strategies, New York: Houghton Mifflin Company.

Ndikana, Andile \& Mayekiso, Tokozile. 2007. “Pre-service Educators' Attitudes Toward Inclusive Education". International Journal of Special Education. Vol. 22, Number 1.

O’Neil, John. 1994. “Can Inclusive Work? A Conversation with Jim Kauffman and Mara Sapon-Shevin". Educational Leadership. 01 (12).

Peraturan Mendiknas Nomor 16 Tahun 2007. Standar Kualifikasi Akademik dan Kompetensi Guru. Jakarta: Badan Standar Nasional Pendidikan.

Santrock, John W. 2007. Perkembangan Anak. (Terjemahan, Jilid I). Jakarta: Penerbit Erlangga.

Smith, David J.2006.Inklusi, Sekolah yang Ramah untuk Semua. (Terjemahan). Bandung: Penerbit Nuansa. 